\title{
Explicating Ethical Corporate Marketing. Insights from the BP Deepwater Horizon Catastrophe: the Ethical Brand that Exploded and then Imploded
}

\author{
John M.T. Balmer, Shaun M. Powell and Stephen A. Greyser
}

\section{John M. T. Balmer}

Brunel Business School, Brunel University, Kingston Lane, London, UB8 3PH, UK.

E-mail: john.balmer@brunel.ac.uk

\section{Shaun M. Powell}

School of Management and Marketing, Faculty of Commerce, University of Wollongong,

New South Wales, 2522, Australia. E-mail: corporatemarketing.org@gmail.com

\section{Stephen A. Greyser}

Cumnock Hall, Harvard Business School, Boston, MA, 02163, USA.

E-mail: sgreyser@hbs.edu

John M.T. Balmer is Professor of Corporate Marketing at Brunel University, London; Quondam Professor of corporate brand/identity management at Bradford University School of Management where, previously, he was Professor of Corporate Identity. His work has been published in leading journals such as the Journal of Business Ethics, California Management Review, European Journal of Marketing, Long Range Planning and The British Journal of Management. E-mail: john.balmer@brunel.ac.uk

Shaun M. Powell is a Senior Lecturer in Marketing and Associate Head of School in the Faculty of Commerce at the University of Wollongong, New South Wales, Australia. He is 
also the co-director of the International Centre for Corporate Marketing, Identity and Branding Studies (www.corporate-marketing.org). His research is focused upon: Corporate Marketing, Corporate Social Responsibility, Sustainability, Corporate Communications, Corporate Branding and Interactive Public Relations. Shaun has published in a variety of international journals and is also an experienced Journal guest editor. E-mail: corporatemarketing.org@gmail.com

Stephen A. Greyser is the Richard P. Chapman Professor of Business Administration (Marketing/Communications) Emeritus at Harvard Business School. He is responsible for 16 books, many journal articles, and over 300 published HBS case studies on brand marketing, advertising/corporate communications, and corporate reputation/identity. With John M.T. Balmer he co-authored "Revealing the Corporation": a seminal book on corporate identity, branding, communications, reputation and corporate marketing. E-mail: sgreyser@hbs.edu

ABSTRACT. Ethical Corporate Marketing-as an organisational wide philosophytranscends the domains of corporate social responsibility, business ethics, stakeholder theory and corporate marketing. This being said, Ethical Corporate Marketing represents a logical development vis-a-vis the nascent domain of corporate marketing has an explicit ethical/CSR dimension and extends stakeholder theory by taking account of an institution's past, present and (prospective) future 
stakeholders. In our article, we discuss, scrutinize and elaborate the notion of Ethical Corporate Marketing. We argue that an Ethical Corporate Marketing positioning is a prerequisite for corporations which claim to have an authentic ethical corporate identity. Our article expands and integrates extant scholarship visa-vis ethical corporate identities, the sustainable entrepreneur and corporate marketing. In delineating the breadth, significance, and challenges of Ethical Corporate Marketing we make reference to the BP Deepwater Horizon (Gulf of Mexico) catastrophe of 2010.

KEY WORDS: BP brand, brand positioning, deepwater horizon, ethical corporate marketing, corporate marketing, ethical corporate identity, sustainable entrepreneurship, sustainability, ethical corporate brands.

\section{Introduction}

Recent business scandals, catastrophes and malpractices (BP, Toyota, and several within the Financial Service Sector) have, again, generated heightened interest in the ethical standards and Corporate Social Responsibility (CSR) remit of organisations in general and of their marketing activities in particular. 
For example, the BP Deepwater Horizon oil catastrophe in the Gulf of Mexico of 2010 has, again, brought to the fore questions relating to corporate social responsibility/ethics in organisations generally and in large corporations in particular. Moreover it has highlighted, albeit to a somewhat limited degree, $\mathrm{BP}^{\prime} \mathrm{s}$ questionable corporate marketing practices. BP's corporate brand positioning whilst emphasising its ethical and CSR credentials has found to have been seriously wanting in the wake of the Deepwater tragedy (Balmer, 2010).

Of course, over recent years marketing and management scholars have challenged institutions to accord increased attention to issues of corporate social responsibility; in addition, many of these scholars have argued that corporations need to be more accountable for the societal consequences of their actions and behaviours (e.g. Cleek and Leonard, 1998; Vidaver-Cohen, 1998; Sen and Bhattacharya, 2001; Bhattacharya and Sen, 2003, 2004; Maignan, Ferrell and Ferrell, 2005; Porter and Kramer, 2006; Ellen, Webb and Mohr, 2006; Du, Bhattacharya and Sen, 2007; Podnar and Golob, 2007; Powell, Elving, Dodd and Sloan, 2009).

From a marketing perspective it has been argued that policy makers should accord importance to issues relating to ethical identity (Gray and Balmer, 2001; Balmer, Fukukawa and Gray, 2007) and, in particular, to corporate marketing. Corporate marketing, as an organisational-wide philosophy should have an explicit ethical/CSR dimension (Balmer 2001). 
The efficacy of according prominence to ethics and CSR within the modern firm is increasingly being recognised by policy makers; this is especially the case in those organisations which operate in sectors where their activities are typically seen as prospectively damaging in CSR/Green terms. British Airways CEO Willie Walsh noted this point with his comment that:

\footnotetext{
"All businesses have to demonstrate now that they are good corporate citizens. It's not enough to say that we are good in terms of corporate performance".

He continued:

"It's particularly important for airlines, where the perception of what we do and the impact on the environment has created a much more heightened awareness of those issues." (Milmo, 2008)
}

Within marketing scholarship, corporate marketing remains a nascent field of inquiry. At its essence, corporate marketing is an adaptation of the original, customer-focussed, marketing orthodoxy centred on products and services. Corporate marketing is an organisational-wide philosophy which has an explicit customer, stakeholder and societal orientation; it entails corporate-level focus and is informed by key organisational concepts such as corporate brand identity, corporate 
identity, corporate communication, corporate image and reputation etc (Balmer, 1998; Balmer and Greyser 2006).

An implicit feature of corporate marketing is that organisations should be mindful of their societal obligations and, taking a temporal perspective, should be mindful of their future/social obligations: profit maximisation and business survival should not be the only basis by which organisations should be assessed and managed (Balmer, 2001, p. 283).

A wide range of organisations broadly fall into this category; they operate in diverse industries; originate from different parts of the globe and are of varying hue and size. They include those whose provenance is characterised by having an enviable corporate brand heritage such as the Co-op Bank in the UK; Cafédirect, Tridos Bank, and the organic chocolatiers Green and Black along with Patagonia (Outdoor clothing: USA), Stonyfield Farm (Organic Dairy Products: USA); Tom's of Maine (Personal care: USA); The Body Shop (Personal Care: UK); and Ben and Jerry's (Ice Cream: USA) - which have been established by social entrepreneurs (Gray and Balmer, 2004; Choi and Gray, 2011).

In addition, we note that different cultural and national traditions may meaningfully inform what to us appear to be ethical corporate marketing practices in different countries (Economist, 2008a). For instance, in Japan this perspective is likely 
to be informed by the mores and precepts of Japanese business which include Shobaido (the way of doing business) and Shonindo (the way of the merchant): these traditions accord importance to CSR, as well as to the environment and to relations with stakeholders and to the local community.

This being said, it is worth reiterating here that what we are speaking of in this paper in terms of Ethical Corporate Marketing relates to those organisations which have an explicit and/or espoused ethical remit; for these institutions there is an imperative to adopt an explicit ethical corporate identity, to be informed by a corporate marketing orientation and to have a supporting Ethical Corporate Marketing philosophy.

Furthermore, there is prima facie evidence to suggest that ethics and CSRcentered companies (Choi and Gray, 2011, p.18-20) are operating in a wide range of industries; these organisations are as diverse as Broad Area Conditioning (operating in the People's Republic of China); Grameen Bank focusing on micro loans to the poor (operating in Bangladesh); Migros food retailers (operating in Switzerland); Ecover environmentally-friendly cleaning products (based in Belgium); Newman's Own salad dressing (based in USA) and Innocent Drinks fruit juices (based in the UK). 
We should also note that institutions which have an Ethical/CSR inheritance and a sterling corporate heritage brand reputation can be attractive to corporations who wish to burnish their CSR credentials. Understandably, they see the acquisition of ethically orientated corporate brands as a favourable proposition. Consider L'Oreal's acquisition of the Body Shop and Unilever's acquisition of Ben and Jerry's. There are of course other imperatives which have spurred policy makers to be concerned with Ethics and CSR and who find the acquisition of an Ethical Corporate Brand highly attractive. In addition, the degree of importance attached to the above can be country-specific. In Great Britain for instance, research undertaken by Chatham House (an influential think tank) among (a) the general public and (b) elite respondents said that ethics should at times take precedence over British national interests (Economist, 2010).

Of course, there is a good deal of on-going debate about CSR: an increasing number of national governments and inter-governmental organisations are taking an active interest in the aforementioned. In Great Britain, for instance, the 2006 Companies Act requires companies to report on their environmental policies and the United Nations promotes corporate social responsibility via its Global Compact initiative. The head of CSR at the accounting firm KPMG has advanced the view that prospective employees increasingly wish to work in institutions where they share the organisations' ethos and values. It is perhaps no surprise then that the Economist Intelligence Unit shows corporate responsibility rising sharply among the priorities 
espoused by policy makers (Economist, 2008). Furthermore, The Economist (2008) noted that a review of 167 studies undertaken over four decades have shown there to be a positive link between companies' social and financial performances-albeit a weak one. More recently a significant milestone has been reached via the International Organisation for Standardisation and the introduction of ISO 26000, providing combined international expertise to all kinds of organisations in various states of economies on how to operate in a socially responsible manner and to contribute to sustainable development (ISO, 2010).

Thus, the occasion of this symposium of papers devoted to ethical corporate marketing in the Journal of Business Ethics is fortuitous since it captures, perhaps, something of the current Zeitgeist; it comes at a time when there is heightened interest in the link between marketing and ethical identity, in marketing and CSR/Ethics, and in the nascent domain of corporate marketing.

Before delving further into scrutinising the BP case there is a need to provide a short overview of corporate marketing as well as proposing the nature of Ethical Corporate Marketing in relation to CSR.

Corporate marketing in context and the broadening of the stakeholder construct 
To reiterate an earlier point, a key aspect of Corporate Marketing is that it has dual foci - both a societal one as well as a multi-stakeholder one (Balmer, 2001); at its essence, it is an organisational-wide philosophy rather than a management function. A key dimension of Corporate Marketing is that it takes a somewhat broader view of stakeholders in that policy makers need to be mindful not only of current and future stakeholders but also those of the past from whose endeavours we invariably derive considerable benefit (Balmer 2001). This brings to mind the observation of Edmund Burke (1729-1797) relating to the partnership between the state and its people; this observation equally pertains to organisations where an Ethical Corporate Marketing philosophy has taken root. Burke states the following:

“(it is) A partnership not only between those who are living, but between those who are dead and those are to be born".

Existing marketing scholarship of products and services-although useful-are limited in scope when applied to the corporate level. For this reason Corporate Marketing requires a radical reworking of the foundations and precepts of marketing. Corporate Marketing can be informed by the notion of identity-based views of the firm based on the notion that multiple identities inhabit as well as inform our comprehension of the modern organisation and by the notion that Corporate Marketing is a gestalt, and is collectively informed by the corporate-level 
constructs of corporate brand identity, corporate image, corporate reputation, corporate communication, etc. Exhibit One provides an overview of Corporate Marketing and Exhibit Two compares and contrasts Corporate Marketing with the more traditional approach to marketing.

\section{TAKE IN EXHIBITS ONE AND TWO HERE AROUND HERE PLEASE}

\section{The corporate marketing mix}

Various corporate marketing mix frameworks have been developed since 1998. The first corporate marketing mix entailed an extension of McCarthy's famous 4PS (product, price, place, promotion) so that this concept was applicable to corporate marketing: this resulted in 10, and then 11, Ps of Corporate Marketing. The first (Balmer, 1998) version of the corporate marketing mix is shown in Appendix 1 and 2. In 2001 a new seven-part mix was introduced with the aim of simplifying the dimensions of the mix via reference to an acronym: $\mathrm{HE}^{2} \mathrm{ADS}^{2}$. The seven dimensions encompasses what the organisation HAS, EXPRESSES, its AFFINITIES, what it DOES, how it is SEEN, its STAKEHOLDERS and ENVIRONMENT. This mix forms, of course, the mnemonic $\mathrm{HE}^{2} \mathrm{ADS}^{2}$. The $\mathrm{HE}^{2} \mathrm{AD}^{2}$ mix is shown in diagrammatic form in Exhibit 3 and the dimensions of the mix are outlined in Appendices 3 and 4. 
There are, however, three substantive differences that distinguish the corporate marketing mix from the traditional marketing mix (Balmer, 2009) in that:

1. The elements of the mix are broader

2. The traditional mix requires a radical reconfiguration

3. The mix elements have distinct disciplinary traditions, underpinned by key corporatelevel constructs, and transcend/broaden traditional institutional boundaries

The latest corporate marketing mix is shown below in the form of sexpartite model (see Exhibit Three) which has the aim of simplifying earlier corporate marketing mixes. An explanation of each dimension of the Corporate Marketing mix is shown in Exhibit Four.

KINDLY TAKE IN EXHIBITS THREE AND FOUR AROUND HERE PLEASE. THANK YOU

From ethical corporate identity and the sustainable entrepreneur to ethical corporate marketing 
Ethical Corporate Marketing-the notion that there exists a category of organisation which has an explicit CSR/Ethical remit and which is underpinned by distinctive CSR/Ethical corporate identity anchors-has very much been informed by collaborative work undertaken on Ethical Corporate Identity; by the notion of the Sustainable Entrepreneur and is a development of existing work relating to Corporate Marketing.

\section{Ethical Identity}

Organisations can be deemed to have an ethical identity by virtue of CSR/Ethics being a prominent feature of their actions and behaviours; those that are reflected in their social connectedness, openness, critical reflexivity, and responsiveness. Institutions which produce mission and values statements (or who espouse ethical precepts regarding their corporate brand positioning along the lines of $\mathrm{BP}$ ) do not necessarily have an ethical identity. As such, there is a need to give due regard to an institution's Actual Identity and to ensure (a) that it is underpinned by ethical/CSR precepts and (b) that communication, perception, brand positioning etc are in meaningful and bilateral alignment. The theoretical notion that institutions have multiple identities and the instrumental imperative of bringing key identity types into meaningful and dynamic alignment has underpinned the ACID Test framework which, since the late 1990s, has undergone several reiterations (see: Balmer et al., 
2009 p. 21). The framework has successfully been applied in various contexts (Powell et al., 2009).

\section{The Sustainable Entrepreneur}

In an initial examination of firms renowned for their sustainable ethical identities, twelve commonalities were identified that help explain why they are sustainable companies and how they have been able to survive the competitive rigours. It was found that these attributes evolved over time and in different ways in each of the organisations: they were not necessarily present when the institutions were established (Gray and Balmer, 2004).

The attributes were identified as follows: 1: company founders all had strong sustainable values; 2: the founders managed their companies for a prolonged period of time; 3: the companies developed mission statements that articulated their sustainable values; 4: the companies developed strong organisational cultures, centered on the notion of sustainability, which were embedded by their founders; 5 : an organisational culture that highly values sustainability; 6: the founders maintained almost complete control of their companies through private ownership or other means; 7: the companies found viable market niches; 8: the companies established stalwart corporate brands; 9: the companies have engaged in numerous public advocacy campaigns; 10: the companies have institutionalised giving 
programmes; 11: the companies have introduced environmentally beneficial changes in their operations that go far beyond regulatory compliance and 12: the companies see themselves as models for others to emulate. It was also noted that the viability of these companies required leaders to successfully navigate issues relating to growth/leadership change. Of especial note is the work of Gray in relation to 'Values-Centered Entrepreneurs' which provides a magisterial examination of an analogous field (Choi and Gray, 2011).

Adopting a broader perspective on sustainability, an increasing number of institutions are resorting to Sustainability Analysis which takes cognisance of an institution's environmental, social and governance (ESG) performance (Grene, 2010). Significantly, BP, using such measures, according to the Swiss consultancy Ecofact, has been a high risk investment in ESG terms since 2006 and has been given a (high risk) score of 60 compared to an industry average which, typically, is in single figures (Grene, 2010).

\section{The BP Deepwater Horizon débâcle and ethical corporate marketing}

$\mathrm{BP}^{\prime} \mathrm{s}$ corporate brand positioning has, for much of the last decade, been underpinned by the company's espoused emphasised ethical and green credentials. BP's controversial branding strategy, in the wake of the Deepwater Horizon catastrophe, has come under intense scrutiny; this mirrored earlier concerns raised as far back as 
2002 (Balmer and Greyser, 2002). Of course, BP's claims relating to its CSR credentials have, increasingly, sat uneasily with the oil behemoth's track record in terms of safety including - but by no means limited to - earlier safety transgressions in South Houston and in Alaska.

It has been observed that the Ethical/CSR positioning adopted by BP for the last decade or more is an example of "Brand Exuberance": a corporate brand positioning that was at best an aspiration and was, in truth, never really attainable; to a large degree, it was divorced from reality (Balmer 2010). In short, BP's erstwhile ethical brand was not underpinned by an ethical identity and, moreover, by an organisational-wide Ethical Corporate Marketing philosophy. This combination is a sine qua non of organisations having an ethical institutional/brand remit. In the wake of this disaster it became clear to the public that what BP communicated vis-a-vis its corporate brand was not supported by institutional behaviour. In theoretical and normative terms, it became clear that key identity modes associated with BP were misaligned and, it would appear, had not been adequately understood or managed.

In the context of this article, $\mathrm{BP}^{\prime} \mathrm{s}$ ethical corporate brand positioning may, in addition, be categorised as an example of 'Hedonist Ethical Corporate Marketing'. It is a case, surely, where $\mathrm{BP}^{\prime} \mathrm{s}$ institutional rhetoric fell short of reality. 
To date, the corporate marketing/corporate branding dimensions of the $\mathrm{BP}$ crisis represent an under-explored dimension of the BP débâcle but, in the fields of ethics and of Corporate Social Responsibility (CSR), it raises some serious issues about why institutions engage in questionable branding and corporate marketing activities and, again, it brings to the fore the relationship among marketing, corporate social responsibility and ethics. For instance, CSR with its focus on stakeholder engagement (versus stakeholder interaction), is mindful of the effect of corporate actions on humanity (Noland and Phillips, 2010). CSR can be more tightly defined as:

“(the) management of stakeholder concern for responsible and irresponsible acts related to environmental, ethical and social phenomena in a way that creates corporate benefit" (Vaaland, Heide and Grønhaug, 2008, p. 931).

In addition, CSR has been explained in terms of where:

"organisations act in a socially responsible manner when they align their behaviours with the norms and demands embraced by their main stakeholders" (Maignan and Ferrell, 2004, p. 6).

By taking account of identity-based perspectives, CSR has also become an important strategy for communicating corporate identity between organisations and 
their stakeholders (Bhattacharya, Korschun and Sen, 2009). It has also been advanced that an especial form of institutional identity - 'ethical identity' - needs to be understood in terms of the relationships between organisations and stakeholders; it views corporations in terms of being part of a wider community (Balmer, Fukukawa and Gray, 2007).

We believe that in all matters of identity and reputation, especially in the ethical realm, corporate claims and promises - and communications about them call for support via a solid underpinning of behaviour and performance.

\section{Historical context: BP and unethical corporate marketing}

In order to understand how the Hedonistic Corporate Marketing activities of BP came about and how this led to the promulgation of an ethical corporate brand positioning, we need to revisit the recent history of the oil behemoth. Let us return to the late 1990s when the company was still known as British Petroleum.

In 1998, in the wake of British Petroleum's merger with the US-owned Amoco, a new oil giant came into existence. It was an entity whose size, shape and international profile had materially changed. The corporation was a decidedly more global, distinctly more American and a definitely less British institution (Balmer and Greyser, 2002). As the then CEO Lord Browne stated at the 2001 International 
Corporate Identity Group Symposium (ICIG) in London, BP was: "global with British roots and headquarters." (Lord Browne of Madingley, 2001).

As part of the process of organisational transformation, BP reflected on the nature of its corporate brand and adopted a radical and courageous, but ultimately disastrous and flawed notion that BP would assert its environmental and green credentials including a concern with sustainable energy sources (Balmer, 2010).

Enacting a number of Corporate Marketing activities in support of its new brand positioning, BP took some audacious steps in terms of distancing itself from its British and Imperial past, thereby consolidating what the corporation had become and confirming where it was going.

Among the bold moves was the adoption of a new corporate brand name - bp -and dropping all reference to its formal name of British Petroleum. This seemed to be reasonable enough and appeared to reflect reality. The adoption of the lower case bp as the corporation's brand (no longer British Petroleum but simply BP) name had the aim of communicating bp's credentials as a self-effacing, less-corporate, and friendly corporate brand. 
In a creative and audacious move, the company's name (bp) became the shorthand for its green positioning with bp standing for 'beyond petroleum'. This new corporate brand positioning was reinforced through its corporate communications activities and the adoption of a new, and striking, visual corporate identity: a pastel and green shaded sunburst (Balmer, 2010). Significantly, the corporation extolled its green credentials and its strategic desire to focus on renewable sources of energy (Balmer and Greyser, 2002).

\section{BP's espoused ethical corporate brand identity and identity misalignment}

However, these Corporate Marketing initiatives were at variance with BP's corporate identity anchors (its "corporate character" to draw on corporate marketing parlance) since $\mathrm{BP}^{\prime} \mathrm{s}$ espoused brand and identity values appeared to be divorced from reality.

Of course, the efficacy of ethical identity alignment has been the subject of earlier Journal of Business Ethics articles (Balmer et al., 2007; Fukukawa et al., 2007). In an earlier issue of California Management Review, BP's questionable - and perhaps unethical -corporate marketing strategy was highlighted in an article taking an identity-based perspective:

“BP's recent (post-merger) corporate positioning strategy emphasised its environmental activities and aspirations (Desired Identity). However, to 
many this seems to be at variance with organisational reality and the Actual Identity of the organisation. BP is quintessentially concerned with oil exploration, refining, and distribution. The environmental activist group Greenpeace, for instance, pointed out that only $1 \%$ of $\mathrm{BP}^{\prime} \mathrm{s}$ activities comes from sustainable sources. While it is clear that from the above that the postmerger BP - while it may be less British and more American, and certainly more global in outlook - has not changed its core business. Although BP has a stated corporate aim of being green-orientated, this environmental positioning (Desired Identity) is an aspiration which (to us) bears arguably questionable resemblance to near-term reality; $\mathrm{BP}^{\prime} \mathrm{s}$ substantive ability to achieve its Desired Identity is constrained, but it may be able to achieve meaningful relative "green" advantage over other energy firms." (Balmer and Greyser, 2002).

In broader contexts, we can note that $\mathrm{BP}^{\prime}$ s ethical positioning may usefully be compared to the 'Ethicalisation' process vis-a-vis ethical corporate identity as outlined by Fukukawa, Balmer and Gray (2007) to show where gaps regarding BP's positioning occurred. The process encompasses: 1 Foundations, Triggers and Motives, 2 Management, 3 Action and Communication, and 4 Image and Stakeholder Perception.

Exhibit Five applies the Ethicalisation approach re ethical corporate identity to BP. 


\section{KINDLY TAKE IN EXHIBIT FIVE HERE}

\section{Discussion}

In reflecting on the nature of Ethical Corporate Marketing we advance the view that this refers to an organisational- wide philosophy. It inhabits those institutions which not only have an explicit CSR/Ethical remit in terms of their organisation's modus operandi/corporate brand positioning, but also importantly reflect this in a meaningful way in terms of their organisational activities and policies - in other words, via their ethical corporate identity (Balmer et al., 2007).

Defining Ethical Corporate Marketing

Ethical Corporate Marketing is a corporate philosophy focussed on ethically/CSRderived organisational values, behaviours and actions in organisations which seek to foster bilateral and mutually beneficial exchange relationships with customers and stakeholders. This exchange occurs through the provision of ethically-orientated brands, services and products that meet and are mindful of current and future societal needs (Balmer, 2010a). 
Of course, in the context of Corporate Marketing, the notion is that the application of the marketing philosophy to organisations per se should have an explicit CSR/Ethical dimension and should also take account of stakeholder concerns. Thus, a central precept of corporate marketing is that a meaningful CSR/Ethical remit will inform all organisations and be present within them; the degree of fidelity to CSR will, naturally, vary among them.

Whilst Ethical Corporate Marketing offers a macro-level approach to CSR/Ethics, within marketing there are significant micro-level approaches to this territory; indicative-but by no means exhaustive- examples include corporate communications, corporate image research and corporate brand crisis management.

For instance, some marketing scholars have identified what they term 'prosocial marketing communications' (Pomering and Dolnicar, 2009, p. 285), which are informed by an organisation's ethical stance/CSR initiatives and have the strategic objective of creating a bond with their stakeholders on salient issues (Maignan and Ferrell, 2004). Often such communication initiatives highlight a firm's green credentials and activities. However, corporate communication initiatives of this nature can be problematical: stakeholders often remain guarded about such claims, and are often skeptical in presuming proactive CSR communications equate to genuine or deep CSR commitment or that actual ethical corporate behaviour 
meaningfully resides within a corporation's identity (Pomering and Dolnicar, 2009; Arvidsson, 2010). This can lead to a form of 'corporate dissonance' if found that rhetoric is not calibrated with behaviour impacting on an organisations reputation (Bernstein, 2009).

In broad terms, a similar communications-based approach underscores the article by Parguel, Benoît-Moreau and Larceneux (2011) in this symposium of papers for the Journal of Business Ethics on Ethical Corporate Marketing. Their study investigates the impact of independent sustainability ratings on consumers' responses to CSR communication. Their findings shed light on how stakeholders are increasingly overwhelmed by escalating CSR claims by organisations, which stakeholders increasingly view to be little more than 'greenwash'. An obvious reason for this is that it can be difficult for outsiders to identify those organisations whose CSR claims are authentic. A second article within the symposium collection on Ethical Corporate Marketing by Stanaland, Lwin and Murphy (2011) examines CSR from the consumer's perspective, focusing on antecedents and consequences of perceived CSR. Their findings support the fact that particular cues, namely perceived financial performance and perceived quality of ethics statements, influence perceived CSR which in turn impacts perceptions of corporate reputation, consumer trust, and loyalty. They draw several conclusions and implications, including the importance of enhancing firm focus toward its ethical commitment and long-term reputation. A third article within the symposium collection on Ethical 
Corporate Marketing by Hansen, Dunford, Boss, Boss and Angermeier (2011) takes an internal organisational perspective to help explain CSR-firm performance linkages and the impact that corporate marketing strategies can have on internal stakeholders such as employees, drawing on theories from corporate marketing and organisational behaviour. Their paper tests the general proposition that employee trust partially mediates the relationship between CSR and employee attitudinal and behavioural outcomes.

When considering values internally it can also be argued that where 'hollow core values' characterise an entity (Urde, 2009, p. 633; Borgerson et al., 2009), this may lead to backlash against the corporate brand (Palazzo and Basu, 2006), and can be damaging because it reveals weaknesses between vision and ethical corporate alignment (Powell, 2007; Powell and Dodd, 2007; Powell et al., 2009). Of course, the BP case is a prime example of this phenomenon as noted earlier (Balmer 2010; British Broadcasting Corporation, 2010).

Curiously, there have also been a few cases where organisations which have credible Ethical/CSR identity traits have failed to communicate this or to see it as part of their corporate strategy: the Co-operative Bank in Great Britain is a case in point (Wilkinson and Balmer, 1996). 
In terms of corporate image research (stakeholders' perceptions), the longitudinal research undertaken by Sir Robert Worcester/IPSOS MORI (2009, p. 586) has found that corporate social responsibility is not viewed as a key means by which many individuals assess organisations. However, his research showed that it becomes salient where stakeholders believe that an institution has not given due regard to its CSR obligations.

Issues of CSR/Ethics have also emerged in relation to research regarding corporate brand crises including the examination of Exxon (the Valdez oil spill incident); the Union Carbide catastrophe (the Bhopal explosion); the Perrier mineral water contamination (benzene traces) among many other cases (Greyser, 2009). Such research concludes that one significant brand crisis dimension is the social responsibility gap (such as the use by American firms of non US labour and questionable working conditions in Asia) leading to a key question:

“Can we as an institution have meaningful, positive and profitable bilateral on-going relationship with customer and other stakeholder groups and communities?" (Balmer and Greyser, 2006).

Within this context, corporate marketing is indeed a boardroom and CEO concern and requires a corporate-wide orientation, where the CEO is the ultimate guardian of the corporation's reputation. 
Reflections on the BP Deepwater Horizon Disaster

In the light of $\mathrm{BP}^{\prime}$ s ethical corporate branding debacle, we should note that policy makers who recognise the efficacy of Ethical Corporate Marketing and of having an identity which is meaningfully informed by CSR identity traits need to focus on the substance rather than on the trappings of the territory. In adopting an ethicallyderived corporate brand positioning/corporate communications, policy makers need to ensure that such policies are (Balmer, 2010):

Credible: reflects reality (grounded in the corporate identity-an entity's defining and differentiating characteristics);

Durable: can be maintained over the long term; Meaningful: valued by customers and stakeholders;

Profitable: of strategic value to the organisation and-in the case of public limited companies-afford benefits to shareholders; AND

Responsible: takes account of its broader corporate responsibility - following the precepts of ethical corporate marketing - and responsible in terms of ensuring that the brand positioning is judicious and is not imprudent.

Of course, the corporate trauma brought about by a catastrophe such as $\mathrm{BP}^{\prime} \mathrm{s}$ Deepwater Horizon tragedy can have the effect of spurring organisations as well as 
their CEOs to undergo a Damascene conversation. With regard to the BP case, this can come with a realisation that in addition to their many strategic concerns the CEO is the organisation's corporate brand manager. This is something that has been stressed for some considerable time now. Moreover, as we can observe from the BP Gulf of Mexico catastrophe, there can be an anthropomorphising of the corporate brand personality. As such, Tony Haywood (BP's CEO at the time of the disaster) found himself in this default position. To many, he became not only the voice and face of BP but, de facto, was BP (Balmer 2010).

A similar damascene conversation increasingly appears to have taken place within organisations from the People's Republic of China regarding the failure to maintain minimum ethical standards across their supply chains. This has come in the wake of the China National Offshore Corporation's attempts to acquire the California oil firm Unocal being scuppered on CSR grounds and for PetroChina to be targeted vis-a-vis its questionable ('unethical') involvement in Sudan (Economist, 2008b).

Trumpeting your organisation's credentials as an Ethical Corporate Marketing concern when the rhetoric is divorced from reality can be especially troublesome as the Chairman of the arms manufacturer in BAE Systems found to his chagrin in 2008 when he told shareholders that BAE was determined to be an ethically-led corporation. His pledge was greeted with boos and hisses with one 
investor noting that BAE was a world leader in weapons but not in ethics and accused the Chairman of "Orwellian" spin (Milmo, 2008). In a similar vein, PepsiCo has a corporate communications narrative which pledges to promote healthier living and yet this hardly seems credible: most of its profits are derived from fattening snacks and drinks (Economist, 2010).

Often, as noted, the questionable positioning is exacerbated by a firm's communications. Among BP's many criticisable actions in the wake of the Gulf blow-out was its corporate communications campaign trumpeting "We will make it right" - before it had even completed capping the underwater well! The many fullpage advertisements also featured the green multi-pettled sunburst logo that symbolised (presumably) the pro-environmental BP identity; alas to many in 2010 it symbolised environmental disaster and corporate failure.

The Efficacy of Ethical Corporate Marketing

In this article we have rehearsed the viewpoint that the nascent domain of corporate marketing represents an organisational-wide, stakeholder-focussed philosophy which is informed by ethics and CSR. Moreover, we have identified a branch of corporate marketing-Ethical Corporate Marketing-which pertains to a category of organisation which has an explicit ethical/CSR remit, and which should be underpinned by an ethical corporate identity and is meaningfully informed by the 
philosophical underpinnings as represented by Ethical Corporate Marketing. This being said, we are mindful, as well as cognisant, of the traditional economic viewpoint of many western organisations which accords primary importance to shareholders and which demands that policy makers create shareholder value. Of especial note were the observations of the celebrated economist Milton Friedman (1970) and a more recent debate between Friedman and others (Friedman et al., 2005) who in celebrated reposte to the growing interest in CSR argued that a firm's social responsibility was to increase profits; a similar standpoint has been adopted as well as noted by others (Bernstein, 2010; Economist, 2010a).

Certainly there is compelling evidence which supports the efficacy of such an approach. In this regard, mention can be made of the collaborative research undertaken by the global poverty relief charity Oxfam and the Anglo-Dutch consumer goods corporation Unilever in relation to the economic impact of Uniliver's operations in Indonesia. The research found that Unilever's activities created a total value of $\$ 630 \mathrm{~m}$ per year; its operations contributed and generated $\$ 130 \mathrm{~m}$ in taxation and the corporation supported 300,000 full-time jobs (Economist, 2008a). As Bernstein (2010) cogently argued in her book making reference to South Africa, the issue is not whether corporations are unethical but that there is not enough of them: a third of that country's population is unemployed. These perspectives might seem to counter our arguments vis-a-vis Corporate Marketing and Ethical Corporate Marketing. Not so. This is because the issue to us is that 
organisations need to be mindful of their ethical and CSR obligations; to us, it does not matter whether this is undertaken by direct or-as in the case with Unilever-by indirect means.

Finally, adapting the observation of Edmund Burke made earlier on in this paper it is worth reflecting that Ethical Corporate Marketing, informed as it is by Corporate Marketing and by CSR and Ethical Identity is an on going and bilateral partnership between an organisation and those who are living, those to be born and, significantly those who are dead but who may have given the organisation its life and vitality.

To us, there is a good deal here that is worthy of deliberation by senior policy makers who are charged with the responsibility of managing organisations having an Ethical Corporate Marketing orientation - a corporate-level philosophy that gives added meaning to the phrase: "To do good by doing well". 


\section{EXHIBIT ONE: Corporate Marketing What is it? What of it?}

Balmer, in his 1998 Journal of Marketing Management article entitled "Corporate Identity and the Advent of Corporate Marketing" argued that a paradigm shift had occurred within marketing, communications, public relations, as well as in organisational behaviour. He argued that there is a pressing need both within practice and within scholarship to adopt both an explicit institutional focus as well as stakeholder foci in the context of synthesising the insights/multi-lateral relationships vis-a-vis the key corporate marketing concepts of corporate identity, image and reputation, corporate communications, and corporate branding literatures (along with those relating to stakeholder theory, marketing, and public relations among others). Three years later (Balmer, 2001, p.283) he argued that corporate marketing also entailed having an explicit societal focus with it being argued that corporate marketing entailed: "Balancing current stakeholder and society's needs."

Corporate marketing is, de facto, an organisational-wide philosophy which expands the traditional marketing philosophy to embrace a stakeholder as well as societal perspectives (Balmer, 2001; Balmer and Greyser, 2006). In addition, corporate marketing can be viewed as an institutional-wide gestalt in that it draws on, and synthesises, various corporate-level perspectives encompassing corporate identity, branding, communications, image, and reputation (Balmer, 2009). Balmer's notion of corporate marketing, in many ways, represents a natural denouement in terms of integrative endeavours within communications (Van Riel, 1995), and identity and identification (Balmer and Greyser, 2002; Brown et al., 2006; Cornelissen et al., 2007). However, whereas integration of communications represents a micro form of integration, corporate marketing is a meta mode of integration. 


\section{EXHIBIT TWO: The differences between Corporate Marketing and Marketing}

(see Balmer 1998; Balmer 2001; Balmer and Greyser 2006 and Balmer 2009)

\section{FOCUS}

Corporate Marketing has an orientation focussed on customers and, importantly, stakeholders; it has an explicit organisational focus.

Traditional Marketing has a customer orientation and a product/service focus (Balmer, 1998).

\section{PHILOSOPHY}

Corporate Marketing is an organisational philosophy - underpinned by a supporting culture - where institutions are engaged in bi-lateral and mutually beneficial exchange relationships with current and prospective customers, and stakeholders.

The approach is also mindful of former constituencies who benefitted future generations (Balmer and Greyser, 2006).

Traditional Marketing is more limited in scope and focuses on bilateral and mutually beneficial exchange relationships with current and prospective consumers. Critically, it also represents an organisational philosophy.

THE TEMPORAL DIMENSION: PAST, PRESENT AND PROSPECTIVE FUTURE Corporate Marketing as a societal/stakeholder philosophy takes into account the organisation's provenance, as well as its current positioning and prospective future one (Balmer, 2001). Corporate Marketing 'managers' are also custodians in this regard.

Traditional Marketing, with its consumer/customer focus, focuses on the current positioning and prospective future one.

\section{ETHICAL AND SOCIETAL CONCERNS}

Corporate Marketing, as an organisational philosophy, demands that institutions give due regard to ethical and societal concerns (Balmer, 2001).

Traditional Marketing regards the above as optional (although, increasingly, as desirable); societal concerns have not always been a prominent theme within marketing.

\section{ORGANISATIONAL FUNCTION}

Corporate Marketing can be viewed as a coordinating function. As such, it provides a 
platform which informs corporate marketing activities via an institution's corporate identity, branding, communications, and reputation management (Balmer, 2009). Traditional Marketing has a coordinating function at the level of the product or service, with the primary goal of addressing consumers and business customers.

\section{EXHIBIT THREE}

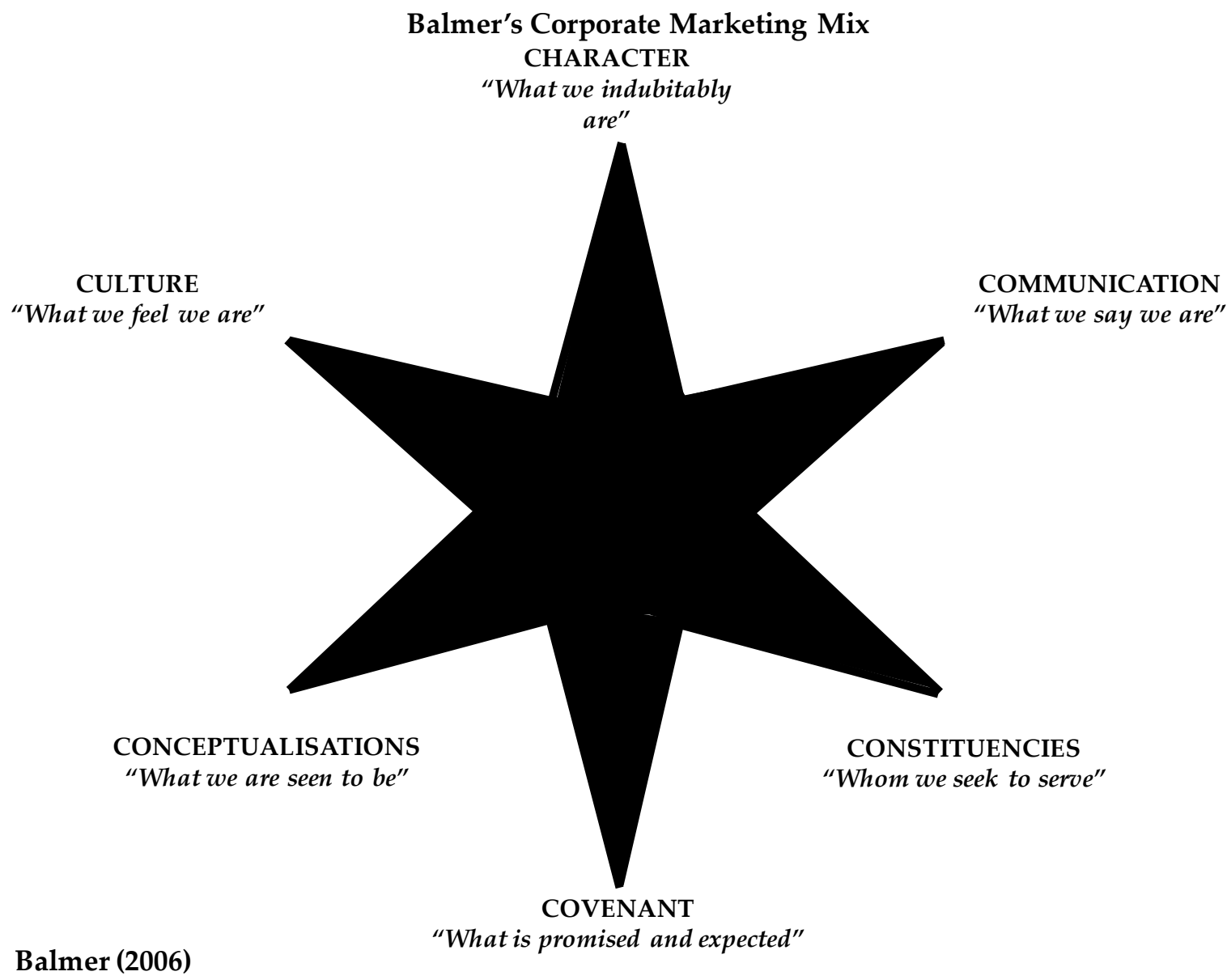

Balmer (2006) in Balmer and Greyser (2006)

The six dimensions of the corporate marketing mix have been explained by Balmer (2009) in terms of a key question which elucidates the saliency and focus of the 
corporate marketing mix concept together with a brief explanation of the corporate level construct from which it is informed. This is replicated in Exhibit Two.

\section{Caveat: the importance of context and custodianship}

It has been observed, however, that two, additional, dimensions require attention in terms of the corporate marketing mix: context and custodianship (Balmer, 2009)

Context refers to those supra and subordinate corporate mix elements which impinge on the mix (identities, reputations and brand identities of nations, suppliers, industries alliances etc) as long as the impact of the political, economic, ethical, social, and technological environment.

Custodianship refers to the key custodial role of senior management in relation to the mix (corporate marketing as with corporate brand management should be a boardlevel concern). For instance, in orchestrating the mix, senior executives (taking identity as an indicative example) may be guided not only by strategic insight but may be guided by their own, firmly held, vision. They might also ignore troublesome facts and developments and alter their cognitive state as a consequence and might, for instance, as a consequence place undue reliance on the trappings rather than substance of organisational change such as the adopting of a new visual identity. 


\section{EXHIBIT FOUR: EXPLAINING THE CORPORATE MARKETING MIX ELEMENTS (Balmer, 2009)}

\section{CHARACTER}

Key Question:" What are the distinctive and defining institutional traits of our organisation?"

Key Concept: Corporate Identity

Organisational traits are those elements that define or meaningfully differentiate one entity from another (organisational activities, markets served, corporate ownership and structure, organisational type, corporate philosophy and corporate history etc.).

CULTURE

Key Question: "What are the collective feelings of employees towards their organisation?" Key Concept/s: Organisational Identification and Corporate Culture

These beliefs are derived from the values, beliefs, and assumptions about the organisation and its historical roots and heritage. Culture provides the context in which staffs engage with each other and with other groups such as customers: employees represent the "front-line" of the organisation.

\section{CONSTITUENCIES}

Key Question: "Which stakeholders are of critical importance to the organisation and why?" Key Concept/s: Stakeholder Theory and Corporate Governance

The philosophy of corporate-marketing is predicated upon the fact that the continuance, and success, of organisations entails meeting the wants and needs of a variety of stakeholder groups: customers are of course (in most instances) of primary importance. Without the support (and identification) of such groups with the entity the organisation might not have a license to operate. Corporate Marketing should also come with a realisation that individuals can belong to several stakeholder groups (as a customer, employee, shareholder and so on.) Stakeholder management may, in broad terms, be viewed as analogous to the comprehension of the importance of a corporation's "constituencies".

\section{CONCEPTUALISATION}

Key Question: "How are we seen by our key stakeholders?"

Key Concept: Corporate Image and Corporate Reputation

Perceptions (conceptualisations) held of the organisation by individuals and 
stakeholder groups can materially effect their sense of association with an organisation/and or corporate brand and is likely to have an impact on behaviour. Corporate image represents the immediate mental picture an individual has of an organisation whereas corporate reputation is the result of facts, beliefs, images and experiences encountered by an individual over time. Corporate image and corporate reputation, of course, interpenetrate.

\section{COMMUNICATION}

Key Question: "Who do we say we are and to whom do we say this?"

Key Concept: Corporate Communications

Corporate communications relates to the totality of controlled messages from the organisation that is directed towards customers, employees and stakeholders.

\section{COVENANT}

Key Question: "What are the distinct components that underpin our corporate brand covenant (corporate brand promise?)

Key Concept: Corporate Brand

A corporate brand is akin to a contract (albeit one that is informal but is nevertheless powerful) and relates to the associations/brand promise that a brand name evokes. As such it can be compared to a corporate covenant. Corporate brands are derived from a particular corporate identity at one point in time and as such corporate brand values are synthesis of key values inherent within the identity. Whereas Balmer holds that legal ownership of a corporate brand is vested in an entity its' emotional ownership (and therein its substantial value) resides with those who have a close association with the brand. 


\section{EXHIBIT FIVE: THE ETHICALISATION PROCESS* AS APPLIED TO BP'S ETHICAL CORPORATE MARKETING \\ (*See: Fukukawa, Balmer and Gray, 2007 vis-a-vis the ethicalisation process)}

(1) Foundations, Triggers and Motives: the altruistic beliefs of leaders; gaining a competitive advantage via a CSR/Ethics positioning; and the influence of legislation and societal norms, can singularly or collectively, cause institutions to strive for an ethical ethos and enhanced social responsiveness. When this happens an organisation's corporate identity has a meaningful CSR/Ethics orientation.

BP: Although policy makers within BP appeared to have altruistic beliefs the resulting ethical orientation of $B P^{\prime}$ 's corporate identity/corporate brand positioning did not appear to be especially strong.

(2) Management: the adoption of the above requires organisations to establish goals, policies and procedures to instil a CSR/Ethical orientation and, for this reason, it becomes a management activity so that an institution has an effective monitoring and review systems vis-a-vis the above. When this occurs, a CSR/Ethics mindset inform policy makers within the institution.

BP: the corporation's espoused ethical orientation was not reflected, sufficiently, in corporate policies, and procedures, and particularly in relation to its corporate identity/corporate brand identity.

(3) Action and Communication: taking into account corporate identity (what we really are as an organisation); corporate communications (what we claim we are) and CSR (being socially responsible) then it is imperative that CSR communications are not decoupled from corporate identity so that an institution is presenting a false identity of what it is.

When a truly Ethical/CSR orientated organisation effectively communicates it's demonstrably apparent Ethical credentials then identity, CSR/Ethics and corporate communication are meaningfully calibrated.

As an identity type, the above is concerned with the so called communicated identity (Balmer and Greyser, 2002) 
BP: This was absent.

(4) Image and Stakeholder Perception: the acquisition of customer/stakeholder perceptions so that the institution is seen to have strong CSR/Ethical credentials is important for the reason that perception guides behaviour. At a simplest level this manifests itself in a willingness to support the organisation as it undertakes its activities in an ethically sensitive manner. When an institution's ethical/CSR activities are recognised as such by customers and stakeholders then this can result in considerable support for the organisation from customers and stakeholders.

One danger is that a communications platform might have created favourable perceptions of an institution's ethical credentials but that both communications and perceptions are divorced from reality.

$B P$ : the corporation's conceived ethical credentials vis-a-vis its corporate identity/corporate brand were held by some stakeholders for a while, but this has now evaporated after the Deepwater Horizon catastrophe. 


\section{LIST OF APPENDIXES}

\section{APPENDIX 1}

Balmer's 1998 Corporate Marketing Mix. The 10ps of Corporate Marketing

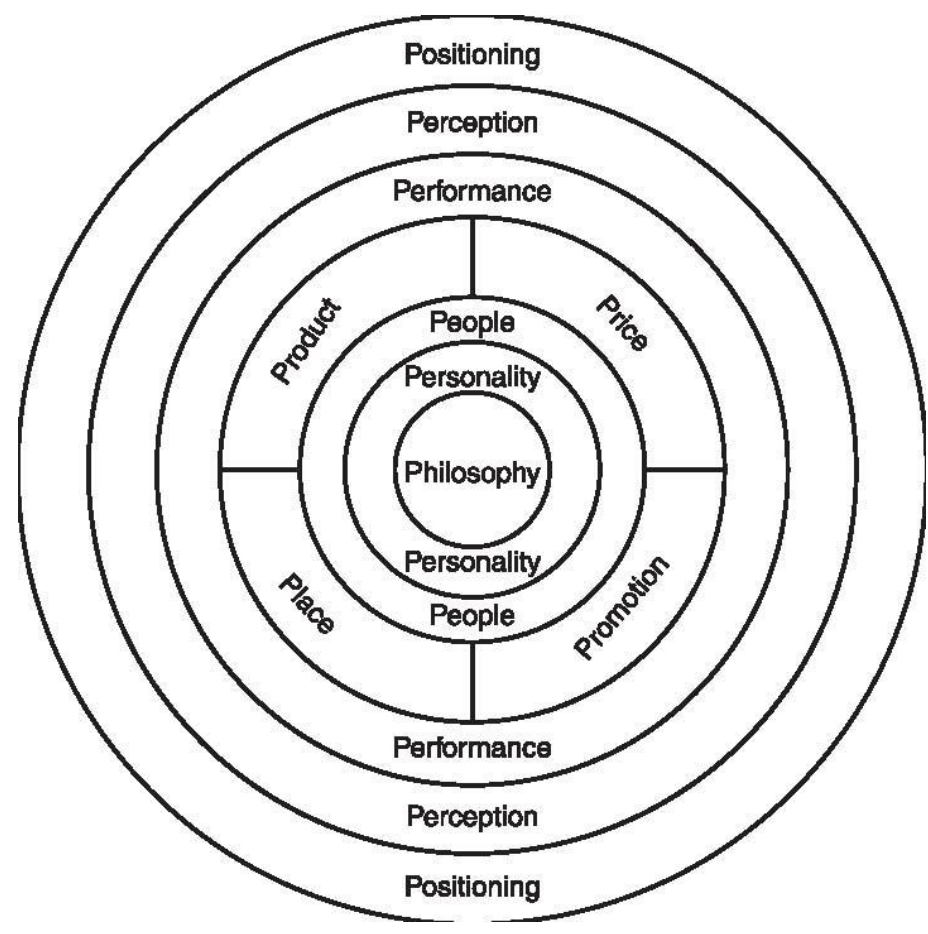

NB: The $11^{\text {th }}$ dimension: Promise (relating to the corporate brand) was subsequently added by Balmer (in Balmer and Greyser 2006) to accommodate the important corporate brand identity type.

Source: Balmer, J.M.T.: 1998, 'Corporate Identity and the Advent of Corporate Marketing', Journal of Marketing Management 14(8), 963-996. 


\section{APPENDIX 2}

\section{Explaining the 10 and 11ps of Balmer's Corporate Marketing Mix of 1998*}

\begin{tabular}{|c|c|}
\hline $\begin{array}{l}\text { PHILOSOPHY } \\
\text { AND ETHOS }\end{array}$ & What the organisation stands for, and the way it undertakes its work \\
\hline PERSONALITY & $\begin{array}{l}\text { The mix of subcultures present within the organisation: these } \\
\text { contribute to the organisation's distinctiveness }\end{array}$ \\
\hline PEOPLE & $\begin{array}{l}\text { Their importance to the organisation's identity (membership of } \\
\text { sub cultural groups); their interface with external stakeholders; } \\
\text { their role in product and service quality }\end{array}$ \\
\hline PRODUCT & $\begin{array}{l}\text { What an organisation makes or does: its core business or } \\
\text { businesses }\end{array}$ \\
\hline PRICE & $\begin{array}{l}\text { What it charges for its products and services, including the } \\
\text { goodwill element in the valuation of its corporate and product } \\
\text { brands; the price of stock; staff salaries }\end{array}$ \\
\hline PLACE & $\begin{array}{l}\text { Distribution channels, company's relationship with } \\
\text { distributors, franchising arrangements, etc. }\end{array}$ \\
\hline PROMOTION & $\begin{array}{l}\text { A concern with Total Corporate Communications: the effects } \\
\text { of the earlier-mentioned primary, secondary, and tertiary } \\
\text { communication; includes visual identification and branding } \\
\text { policy }\end{array}$ \\
\hline PERFORMANCE & $\begin{array}{l}\text { How the organisation's performance is rated by its key } \\
\text { stakeholders vis-à-vis the organisation's espoused philosophy } \\
\text { and ethos, and how it is rated against competitors }\end{array}$ \\
\hline PERCEPTION & $\begin{array}{l}\text { Questions relating to corporate image and corporate reputation. } \\
\text { Perception of the industry/country of origin may also be } \\
\text { significant }\end{array}$ \\
\hline POSITIONING & $\begin{array}{l}\text { In relation to important stakeholders, competitors, and the } \\
\text { external environment }\end{array}$ \\
\hline
\end{tabular}

PROMISE * The expectations associated with the corporate brand name

Source: Balmer, J.M.T.: 2001, 'Corporate Identity, Corporate Branding and 
Corporate Marketing: Seeing through the Fog', European Journal of Marketing 35(3/4), 248-291.

* The Promise dimension of the mix was subsequently added by Balmer (in Balmer and Greyser 2006) and encompasses the important dimension of the corporate brand.

\section{APPENDIX 3}

Balmer's Second Corporate Marketing Mix (2001): $\mathrm{HE}^{2} \mathrm{ADS}^{2}$

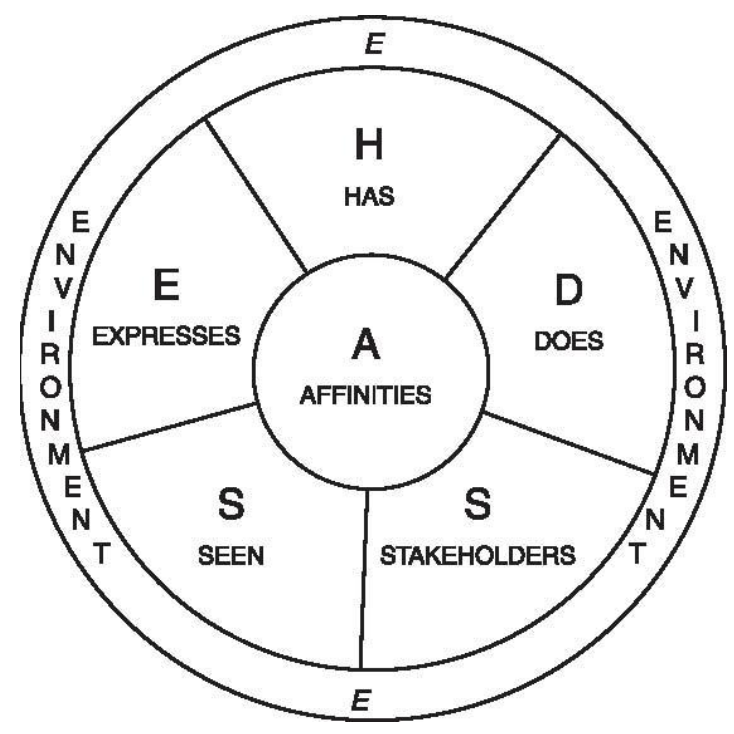

Source: Balmer, J.M.T.: 2001, 'Corporate Identity, Corporate Branding and Corporate Marketing: Seeing through the Fog', European Journal of Marketing 35(3 and 4), 248-291. 


\section{APPENDIX 4 \\ Explaining the Seven Dimensions $\left(\mathrm{HE}^{2} \mathrm{ADS}^{2}\right)$ of Balmer's Second Corporate Marketing Mix of 2001}

H: What the organisation HAS.

Includes the organisation's structure, history and legacy, property and equipment, reputation, investment interests in other organisations.

E: What the organisation EXPRESSES.

Integrates primary communication (products and services performance), secondary (formal communication policies), and tertiary communications (word of mouth, media communication, \competitor communication, and spin).

$\mathbf{E}^{2}:$ The ENVIRONMENTAL context

Takes account of the Political, Economic, Ethical, Social, Technological etc Environment and its impact on an organisation's corporate marketing activities/philosophy.

A: The AFFINITIES of employees.

Includes the degree of positive or negative associations with employees to various sub cultural groups including corporate ones (old, new, ascendant, subsidiary, departmental).

D: What the organisation DOES.

Includes all the elements of McCarthy's 4Ps mix with the exception of promotion (see EXPRESSES above).

S: How the organisation is SEEN. Includes data regarding current perceptions of the organisation's image and reputation, and organisational awareness and profile; data on past performance, knowledge, beliefs, and expectations; salience of the corporate branding covenant.

$\mathbf{s}^{2}$ : The organisation's key STAKEHOLDER groups and networks. Noting and prioritising the organisation's key groups, networks, and individuals in the context of the organisation's strategy, and in the context of different markets and situations. 


\section{(kindly take in appendixes 1 to 4 before the references please):}

\section{References}

Arvidsson, S.: 2010, 'Communication of Corporate Social Responsibility: A Study of the Views of Management Teams in Large Companies', Journal of Business Ethics, DOI 10.1007/s10551-010-0469-2.

Balmer, J.M.T.: 1998, 'Corporate Identity and the Advent of Corporate Marketing', Journal of Marketing Management 14(8), 963-996.

Balmer, J.M.T.: 2001, 'Corporate Identity, Corporate Branding and Corporate Marketing: Seeing Through the Fog, European Journal of Marketing 35(3/4), 248-291.

Balmer, J.M.T.: 2009, 'Corporate marketing: Apocalypse, Advent and Epiphany', Management Decision 47(4), 544-572.

Balmer, J.M.T.: 2010, 'The BP Deepwater Horizon Debacle and Corporate Brand Exuberance', Journal of Brand Management 18(2), 97-104.

Balmer, J.M.T.: 2010a, Definition of Ethical Corporate Marketing from class notes: MSc in Corporate Brand Management, Brunel University, London.

Balmer, J.M.T. and S.A. Greyser: 2002, 'Managing the Multiple Identities of the Corporation', California Management Review 44(3), 72-86.

Balmer, J.M.T. and S.A. Greyser: 2006, ‘Corporate Marketing: Integrating Corporate Identity, Corporate Branding, Corporate Communications, Corporate Image and Corporate Reputation', European Journal of Marketing 40(7/8), 730-741.

Balmer, J.M.T., K. Fukukawa and E.R. Gray: 2007, 'The Nature and Management of Ethical Corporate Identity: A Commentary on Corporate Identity, Corporate Social Responsibility and Ethics', Journal of Business Ethics 76(1), 7-15. 
Balmer, J.M.T., H, Stuart and S.A. Greyser: 2009, 'Aligning Identity and Strategy: Corporate Branding at British Airways in the Late 20th Century', California Management Review 51(3), 6-23.

Bernstein, A.: 2010, The Case for Business in Developing Economies, (London. Viking Books).

Bernstein, D.: 2009, 'Rhetoric and Reputation: Some Thoughts on Corporate Dissonance', Management Decision 47(4), 603-615.

Bhattacharya, C.B. and S. Sen: 2003, 'Consumer - Company Identification: A Framework for Understanding Consumers' Relationships with Companies', Journal of Marketing 67(2), 76-88.

Bhattacharya, C.B and S. Sen: 2004, 'Doing Better at Doing Good: When, Why, and How Consumers Respond to Corporate Social Initiatives', California Management Review 47(1), Fall, 9-24.

Bhattacharya, C.B., D. Korschun and S. Sen: 2009, ‘Strengthening StakeholderCompany Relationships Through Mutually Beneficial Corporate Social Responsibility Initiatives', Journal of Business Ethics 85 (Supplement 2), 257-272.

Borgerson, J.L., J.E. Schroeder, M.E. Magnusson and F. Magnusson: 2009, 'Corporate Communication, Ethics, and Operational Identity: A Case Study of Benetton', Business Ethics: A European Review 18(3), 209-223.

British Broadcasting Corporation: 2010, ‘BP Faces Choppy Waters after Huge Oil Spill', http://news.bbc.co.uk/2/hi/americas/8652448.stm 29th April, 2010 accessed 1st May 2010.

Brown, T.J., P.A. Dacin,. M.G. Pratt and D.A. Whetten: 2006, 'Identity, Intended Image, Construed Image, and Reputation: An Interdisciplinary Framework and Suggested Terminology', Journal of the Academy of Marketing Science 34(2), 99-106.

Choi, D.Y. and E.R. Gray: 2011, Values-Centered Entrepreneurs and their Companies, (New York and London, Routledge).

Cleek, M.A. and S.L. Leonard: 1998, 'Can Corporate Codes of Ethics Influence Behavior?', Journal of Business Ethics 17(6), 619-630. 
Cornelissen, J.P., S.A. Haslam and J.M.T. Balmer: 2007, 'Social Identity, Organizational Identity and Corporate Identity: Towards an Integrated Understanding of Processes, Patternings and Products', British Journal of Management 18(s1), s1-s16.

Du, S., C.B. Bhattacharya and S. Sen: 2007, 'Reaping Relational Rewards from Corporate Social Responsibility: The Role of Competitive Positioning', International Journal of Research in Marketing 24(3), 224-241.

Economist: 2008, Just Good Business, Special Report on Corporate Social Responsibility, January 19, 3-6.

Economist: 2008a, The Next Question. Does CSR Work? Special Report on Corporate Social Responsibility, January 19, 10.

Economist: 2008b, Going Global. CSR is Spreading Around the World but in Different Guises, Special Report on Corporate Social Responsibility, January 19, 18-20.

Economist: 2010, Business and NGOs, Reaching for a Longer Spoon, June 5, 75.

Economist: 2010a. Shumpeter. Companies aren't Charities. October 23, 82.

Ellen, P., D. Webb and L. Mohr: 2006, 'Building Corporate Associations: Consumer Attributions for Corporate Socially Responsible Programs', Journal of the Academy of Marketing Science 34(2), 147-157.

Friedman, M.: 1970, 'The Social Responsibility of Business is to Increase Profits', The New York Times Magazine, September 13.

Friedman, M., J. Mackey, and T.J Rodgers: 2005, 'Rethinking Social Responsibility: Putting Customers ahead of Investors', Reason Magazine, October.

Fukukawa, K., J.M.T. Balmer, and E.R. Gray: 2007, 'Mapping the Interface Between Corporate Identity, Ethics and Corporate Social Responsibility', Journal of Business Ethics 76(1), 1-5.

Gray, E.R. and J.M.T Balmer: 2001, 'Ethical Identity: What is it? What of it?', Bradford School of Management Working Paper Series, 01/15.

Gray, E.R. and J.M.T Balmer: 2004, 'The Sustainable Entrepreneur', Bradford School of Management Working Paper Series, 04/14.

Also see: $\underline{\text { www.brad.ac.uk/acad/management/external/pdf/.../Booklet 04-14.pdf }}$ 
Grene, S.: 2010, BP Crisis Highlights Value of Sustainability Exploration, Financial Times, June 14: 8 (FTfm section).

Greyser, S.A.: 2009, 'Corporate Brand Reputation and Brand Crisis Management', Management Decision 47(4), 590-602.

Hansen, S.D., B.B. Dunford, A.D. Boss, R.W. Boss and I. Angermeier: 2011, 'Corporate Social Responsibility and the Benefits of Employee Trust: A CrossDisciplinary Perspective', Journal of Business Ethics (in press).

ISO: 2010, 'ISO 26000 Project Overview',

http://www.iso.org/iso/iso catalogue/management and leadership standards/social responsibility/sr iso26000 overview.htm\#sr-1 accessed 15 ${ }^{\text {th }}$ March 2011.

Lord Browne of Madingley: 2001, Unpublished Key Note Address Delivered at the International Corporate Identity Group (ICIG) Symposium held at Brown's Hotel, London.

Maignan, I. and O.C. Ferrell: 2004, 'Corporate Social Responsibility and Marketing: An Integrative Framework', Journal of the Academy of Marketing Science 32(1), 3-19.

Maignan, I., O.C. Ferrell and L. Ferrell: 2005, 'A Stakeholder Model for Implementing Social Responsibility in Marketing', European Journal of Marketing 39(9/10), 956-977.

Milmo, D.: 2008, 'BA Humbug-or the Best Way of Doing Good?', The Guardian, November 11, 27.

Noland, J. and R. Phillips: 2010, 'Stakeholder Engagement, Discourse Ethics and Strategic Management', International Journal of Management Reviews 12(1), 39-49.

Palazzo, G., and K. Basu: 2006, 'The Ethical Backlash of Corporate Branding', Journal of Business Ethics 73(4), 333-346.

Parguel, B., F. Benoît-Moreau and F. Larceneux: 2011, 'How Sustainability Ratings Might Deter "Greenwashing": A Closer Look at Ethical Corporate Communication', Journal of Business Ethics (in press).

Podnar, K. and U. Golob: 2007, 'CSR Expectations: The Focus of Corporate Marketing', Corporate Communications: An International Journal 12(4), 326-340. 
Pomering, A. and S. Dolnicar: 2009, 'Assessing the Prerequisite of Successful CSR Implementation: Are Consumers Aware of CSR Initiatives?', Journal of Business Ethics 85 (Supplement 2), 285-301.

Porter, M.E. and M.R. Kramer: 2006, 'Strategy and Society: The Link between Competitive Advantage and Corporate Social Responsibility', Harvard Business Review 84(12), 78-92.

Powell, S.M.: 2007, 'Organisational Marketing, Identity and the Creative Brand', Journal of Brand Management 15(1), 41-56.

Powell, S.M. and C. Dodd: 2007, 'Managing Vision and the Brand within the Creative Industries', Corporate Communications: An International Journal 12(4), 394-413.

Powell, S.M., W.J.L. Elving, C. Dodd and J. Sloan: 2009 'Explicating Ethical Corporate Identity in the Financial Sector', Corporate Communications: An International Journal 14(4), 440-455.

Riel, C.B.M. van.: 1995, 'Principles of Corporate Communication', (London, Prentice Hall).

Sen, S. and C.B. Bhattacharya: 2001, 'Does Doing Good Always Lead to Doing Better? Consumer Reactions to Corporate Social Responsibility', Journal of Marketing Research 38(2), 225-243.

Stanaland, A.J.S., M.O. Lwin and P.E. Murphy: 2011, 'Consumer Perceptions of the Antecedents and Consequences of Corporate Social Responsibility', Journal of Business Ethics (in press).

Urde, M.: 2009, 'Uncovering the Corporate Brand's Core Values', Management Decision 47(4), 616-638.

Vaaland, T.I., M. Heide and K. Grønhaug: 2008 ‘Corporate Social Responsibility: Investigating Theory and Research in the Marketing Context', European Journal of Marketing 42(9/10), 927-953.

Vidaver-Cohen, D.: 1998, 'Moral Climate in Business Firms: A Conceptual Framework for Analysis and Change', Journal of Business Ethics 17(11), 1211-1226.

Wilkinson, A. and J.M.T. Balmer: 1996, 'Corporate and Generic Identities: Lessons from the Co-operative Bank, International Journal of Bank Marketing 14(4), 23-35. 
Worcester, R. Sir.: 2009, 'Reflections on Corporate Reputations', Management Decision 47(4), 573-602. 